\title{
Student Engagement in a Team-Based Capstone Course: A Comparison of What Students Do and What Instructors Value
}

\author{
OP McCubbins ${ }^{\mathrm{a}}$, Thomas H. Paulsen ${ }^{\mathrm{b}}$, Ryan Anderson ${ }^{\mathrm{c}}$ \\ ${ }^{a}$ Tennessee Tech University, ${ }^{b}$ Morningside College, ${ }^{c}$ Sauk Valley Community College
}

Student engagement is an important consideration across all levels of education. The adoption of student-centered teaching methods is an effective way to increase student engagement. Student engagement is at risk when instructor expectations and student participation in purposeful engagement activities are not aligned. Traditionally, student engagement is measured at the institutional level, which proves less than useful to instructors who wish to gauge engagement in specific courses in higher education. In this study, we sought to determine classroom level engagement in a capstone farm management course recently converted to the team-based learning format by comparing student perceptions regarding participation in engagement-specific activities with the instructors' perceived importance of those same activities. The Classroom-Level Survey of Student Engagement (CLASSE) was utilized to collect student participation and instructor importance data. Data were examined utilizing a 2x2 quadrant analysis. Congruence between student participation frequency and instructor importance was found between $73.7 \%$ of the educational activities, while discrepancies were found on $26.3 \%$ of educational activities. Overall, students who completed the team-based learning-structured farm management course were physically and psychologically engaged in the learning environment. It is recommended that team-based learning be implemented in other courses within agricultural education to examine its utility in other contexts.

Keywords: student engagement, active learning, team-based learning, capstone course

\section{Introduction and Literature Review}

Student engagement is an important factor to consider within the landscape of higher education, and it has experienced considerable growth in recent years as a topic of interest for educational researchers (Bowen, 2005; Mandernach, 2015). The basis for this increased interest is ultimately driven by a mission of higher education to improve student learning (Reschly \& Christenson, 2012). Additionally, it has been argued that student engagement is the most important factor impacting student learning and development ( $\mathrm{Hu} \&$ Kuh, 2002), and has been identified as an effective indicator of student outcomes (Kuh, Pace, \& Vesper, 1997). Student engagement can be a useful tool to understand or improve various student outcomes as well (Finn \& Zimmer, 2012). It would stand to reason that with its considerable importance, engagement has been well defined in the extant literature but “...definitional clarity has been elusive” (Appleton, Christenson, \& Furlong, 2008, p. 370), possibly due to a shifted focus several times in the last few decades (Kuh, 2009; McCormick, Kinzie, \& Gonyea, 2013). As a result, a variety of definitions and conceptualizations of what is meant within the engagement literature have been extended. Several researchers have promulgated this issue in recent years (Appleton, et al., 2008; Axelson \& Flick, 2011; Bowen, 2005; Shulman, 2002). Specifically, Bowen (2005) declared that a consensus on what is meant by engagement or why it is important is nonexistent, while Shulman (2002) posited that learning begins with engagement, therefore making it one of the most important aspects in the learning process.

Some researchers purport engagement should be viewed as a three-part typology that includes behavioral, emotional, and cognitive aspects (Fredericks, Blumenfield, \& Paris, 2004; Jimerson, Campos, \& Grief, 2003; Lam et al., 2012; Marx, Simonsen, \& Kitchel, 2016; Sinclair, Christenson, Lehr, \& Anderson, 2003). A multidimensional view of the engagement construct (Appleton et al., 2008; Appleton et al., 2006) highlights its complexity as it is often regarded as a meta-construct (Axelson \& Flick, 2011; Jimerson et al., 2003; Lam et al., 2012; Sinclair et al., 2003). Specifically, Fredericks et al. (2004) identified three dimensions of student engagement that included behavioral, emotional, and cognitive factors; a conceptualization echoed by Marx, et al. (2016) in their 
examination of student course engagement. The wideranging definition of engagement, while contributing to the "conceptual haziness" of the construct (Reschly \& Christenson, 2012), is well suited for purposes of institutional accountability. This sentiment seemingly aligns with Marx et al.'s (2015) assertion that "engagement is most extensively analyzed globally within the total college experience through the works and related works of George Kuh” (p. 213).

Kuh (2003) explained, "The engagement premise is deceptively simple, even self-evident. The more students study a subject the more they learn about it” (p. 25 ). This was not a dismissal of the intricacies relating to student engagement, but a means to measure how institutional practices impact the students they serve. Axelson and Flick (2011) contended the adoption of a narrow definition of student engagement, one that focused on student involvement in the learning process, would result in the utilization of student involvement data for immediate program improvement decisions. Specifically, Axelson and Flick (2011) declared, "To support the research and program improvement uses of student engagement, we believe that a narrower definition of the term is needed, one that is restricted to students' level of involvement in a learning process" (p. 41). More meaningful programmatic improvements regarding student engagement within higher education would have an immediate impact on the undergraduate educational experience (Ewell \& Jones, 1996). These sentiments are shared by several researchers throughout the educational literature (Banta, Pike, \& Hansen, 2009; Hemsley-Brown \& Sharp, 2003; McCormick, et al., 2013).

Ewell and Jones (1996) discussed the general public's pressure on institutional accountability that led to an increase in the assessment of student outcomes during the 1980s. A serious disconnect existed between the faculty responsible for teaching students and the technical assessment specialist conducting the outcomes assessments. This led to faculty resistance based on the limited utility of information relative to improving the teaching and learning process (Ewell \& Jones, 1996). The noted disconnect led to recommendations by several researchers to develop measurement procedures to collect information on specific instructional approaches and student experiences to be included in institutional accountability measures (Ewell \& Jones, 1996; Ewell, 1996; Pace, 1984). To determine practices with positive impacts on students at the postsecondary level, Chickering and Gamson (1987) synthesized decades of research to develop “...seven broad principles for good practice in undergraduate education” (Cruce, Wolniak, Seifert, \& Pascarella, 2006, p. 365). Chickering and Gamson (1999) also sought to set forth accessible, synthesized evidence for faculty, administrators, higher education agencies, and policymakers. The principles were developed with practicality and understandability in mind. Chickering and Gamson’s (1987) good practices in undergraduate education included: 1) encouraging contacts between students and faculty, 2) developing reciprocity and cooperation among students, 3) using active learning techniques, 4) giving prompt feedback, 5) emphasizing time on task, 6) communicating high expectations, and 7) respecting diverse talents and ways of learning (p. 2). Ewell and Jones (1996) noted the overwhelming support and value placed upon the principles as process indicators of student success because they were "... agreed upon by the wider academic community, and are known to work" (p. 7). The value was strengthened because they could be utilized in determining how committed institutions were in improving the undergraduate educational experience. Kuh, et al. (1997) echoed the importance of utilizing these types of process indicators for examining student outcomes. The publication and support of these principles has spawned a surfeit of educational research interested in examining the interaction of the seven principles on student outcomes (Bangert, 2004).

Viewed as a result or as a process indicator, the literature regarding student engagement provides "one unequivocal conclusion... the impact of college on learning and development is largely determined by an individual's quality of effort and level of involvement in both the curricular and cocurricular offerings on campus” (McCormick, et al., 2013, pp. 53-54). This conceptualization of student engagement highlights the importance of the institutional practices of higher education. Regarding institutional conditions, the teaching and learning approaches utilized are of considerable importance to student success. Unsettlingly, those who teach within institutions of higher education are generally not trained in any formal means of pedagogy, curriculum design, or assessment strategies (Maxwell, Vincent, \& Ball, 2011).

Based upon the current literature in agricultural education contexts, these indicators of good practice resonate at a much lower frequency than desired. Many studies assert that faculty members within colleges of agriculture are most competent or efficacious in lecturing (Balschweid, Knobloch, \& Hains, 2014; Blickenstaff, Wolf, Falk, \& Foltz, 2015; Wardlow \& Johnson, 1999). Blickenstaff et al. (2015) reported a critical need for faculty professional development training in the areas of engaging students in the learning process, improving student reading/writing, and promoting the development of critical thinking ability of students. College of Agricultural and Life Sciences faculty must engage students in the learning process to contribute to long-term outcomes (e.g., employability based on transferable skills such as communication, critical thinking, and problem solving) (Blickenstaff et al., 2015). These long-term outcomes can be addressed through instructional approaches that intentionally incorporate active learning strategies. Previous studies have found low levels of student engagement in lecturebased courses (Chickering \& Gamson, 1987; Ewing \& Whittington, 2009; McCarthy \& Anderson, 2000; 
Mennenga, 2012), while active learning strategies have shown an increase in student engagement (Lightner, Bober, \& Willi, 2007; Tucker, 2012). Estepp and Roberts (2013) recommended instructors employ a variety of active learning strategies including discussion, team-based activities, projects, and presentations to promote student engagement.

\section{Theoretical/Conceptual Framework}

The framework for this study is grounded in Astin's (1999) Student Involvement Theory (SIT) and the engagement literature. SIT is grounded in decades of research elucidating that involvement references the "...quantity and quality of the physical and psychological energy students invest in the college experience” (Astin, 1999, p. 528). Specifically, SIT is rooted in Astin's (1975) longitudinal work on student persistence as it related to involvement. Student lack of involvement is often signaled by passivity. Astin (1999) explained that the behavioral aspect of a student's involvement is critical. In other words, what the student does in the learning environment signifies involvement. Five postulates were developed in regards to SIT and include: 1) involvement is the investment of physical and psychological energy in objects (generalized or specific), 2) involvement occurs along a continuum for all students, 3) involvement can be measured both quantitatively and qualitatively, 4) the quality and quantity of involvement is a predictor of student learning and development, and 5) educational policy or practice can only be deemed effective based on the capacity to increase student involvement (Astin, 1999). When concentrating efforts on instructional approachesthose that nurture student involvement-higher education institutions can expect significant benefits (Smith, Sheppard, Johnson, \& Johnson, 2005).

The evolution of the engagement construct led to considerable dissension on the operational definition of student engagement (Appleton, et al., 2008; Bowen, 2005). Kuh (2009) espoused that the modern conceptualization of engagement emanated from previous research involving time on task, quality of effort, student involvement, social and academic integration, good practice for undergraduate education, as well as student outcomes research.

Kuh (2001) synthesized existing research on the impact that process indicators (e.g., specific educational activities) had in relation to student success in an effort to reform institutional practices. His goal was to provide data that could be utilized by higher education institutions in making informed decisions to provide quality educational practices to the students they serve. This resulted in the development of the National Survey of Student Engagement (NSSE), a valid and reliable assessment instrument grounded in research tied to practices that had high correlations with desired student development outcomes (Kuh, 2009). NSSE's core purposes include improving the undergraduate experience, documenting good practice, and public advocacy (Kuh, 2009). These process indicators have been empirically linked to student success. Cruce, et al. (2006) described the research supporting the predictive validity of each of Chickering and Gamson's (1987) principles. The weight of evidence synthesized by Cruce et al. related to each principle is substantial.

Conceptually, this study is situated within Kuh, Kinzie, Buckley, Bridges, and Hayek's (2007) model on factors that affect student success (Figure 1). Kuh et al. (2007) purported student engagement lies at the intersection of institutional conditions and student behaviors. This study focused on the central area of Figure 1, paying attention to teaching and learning approaches (institutional conditions) and various student behaviors.

Student behaviors include study habits, involvement with other peers, interaction with faculty members, and their motivation to participate in other educational activities. Institutional practices involve academic support, the general campus environment, and teaching and learning approaches provided by the institution. The coalescence of institutional conditions and student behaviors have the potential to contribute to student engagement, which is empirically linked to student satisfaction, learning gains, and other long term outcomes (i.e., graduation, employment, and lifelong learning) (Kuh et al., 2007).

\section{Purpose and Objectives}

Learning environments may be less effective when a mismatch exists between teachers' and students' expectations and conceptions of the teaching and learning process (Chalmers \& Fuller, 1996). Smallwood (2008) praised the utility of student engagement data when collected at the classroom level and noted the increased likelihood for curriculum improvement when collected at the local level. The purpose of this study was to determine classroom level engagement by comparing student perceptions regarding participation in engagement-specific activities with the instructors' perceived importance of those same activities. This study was substantiated by Priority Area Four of the American Association for Agricultural Education (AAAE), National Research Agenda (Edgar, Retallick, \& Jones, 2016; Roberts, Harder, \& Brashears, 2016). The investigation of various teaching approaches may help identify methods that appropriately promote “...engagement and learning” (Edgar et al., p. 39) within the classroom. Specific objectives that guided this study included:

1. Determine the importance of engagementspecific activities within the AGEDS 450 course as reported by the instructional team (i.e., instructor, teaching assistant, and farm operator). 


\section{What Matters to Student Success}

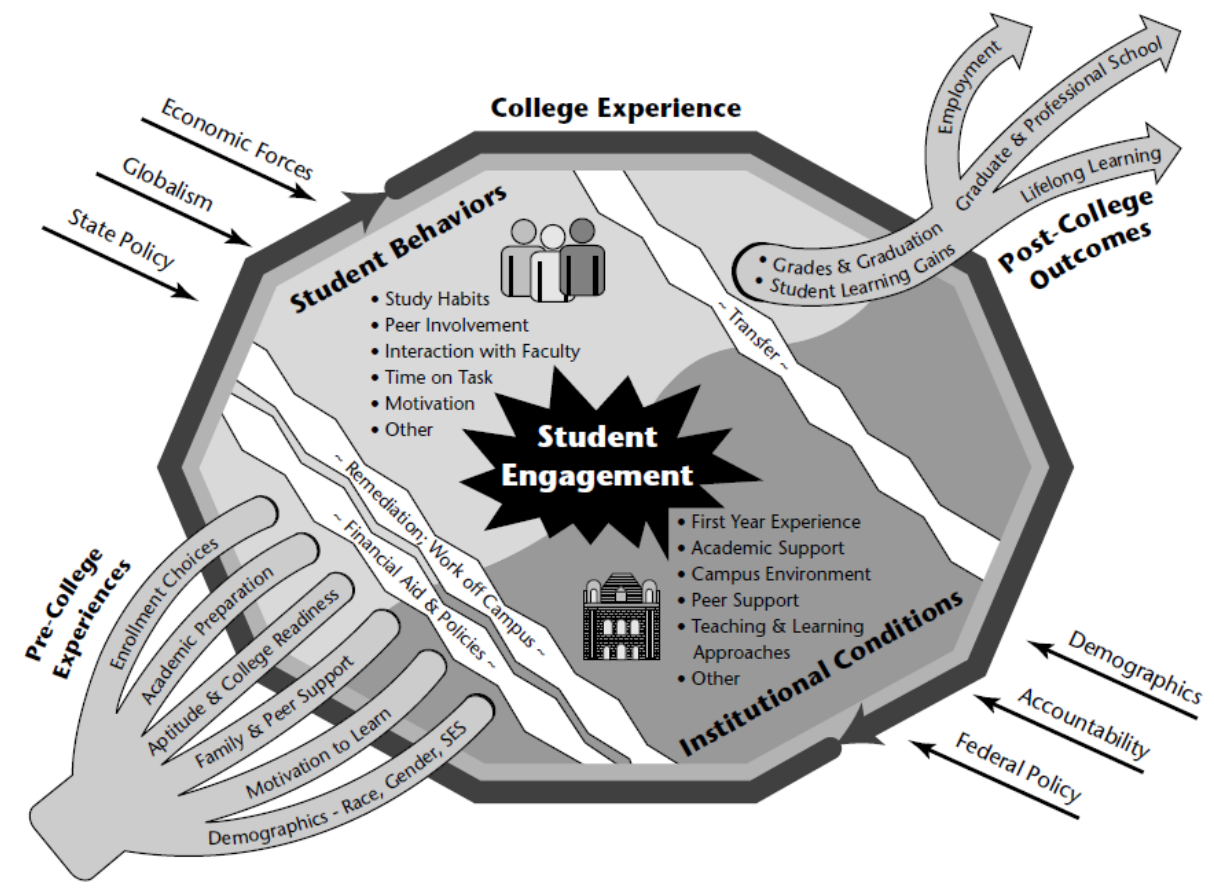

Figure 1. What matters to student success. From "Piecing Together the Student Success Puzzle: Research, Propositions, and Recommendations,” by G. D. Kuh, J. Kinzie, J. A. Buckley, and J. C. Hayek, 2007, ASHE Higher Education Report, 32(5), p. 11. Reprinted with permission.

2. Determine the frequency of student participation in engagement-specific activities within AGEDS 450.

3. Determine congruency between importance and frequency of engagement-specific activities within AGEDS 450.

\section{Methods and Procedures}

This study is part of a larger, more comprehensive study designed to examine the effectiveness of the implementation of team-based learning (TBL) in a capstone course in a robust manner. The present study employed a non-experimental, descriptive research design, to measure student engagement in a TBLformatted capstone course. All students enrolled in the AGEDS $450(n=121)$ course for the fall $2015(n=61)$ and spring $2016(n=60)$ semester were identified as the target population. AGEDS 450 is a capstone course for Agricultural Studies majors at Iowa State University (ISU) and providing students with real-world experiences grounded in the tenets of Crunkilton et al.'s (1997) capstone course components is its primary outcome. The course was revised to a TBL structure in 2014. TBL is a student-centered teaching method that emphasizes small group work and the application of content (Michaelsen et al., 2004). Students enrolled in the course met for a combined lecture period on campus and were split into two laboratory sections that met on the farm once per week (Paulsen, 2010). Student engagement at the classroom level was of particular interest in this study. As such, an instrument derived from the National Survey of Student Engagement (NSSE) (Kuh, 2004), called the Classroom Level Survey of Student Engagement (CLASSE) was utilized.

CLASSE is a two-part instrument "that compares faculty expectations with what students report experiencing in a class" (Ouimet \& Smallwood, 2005, p. 13). The NSSE instrument, based on a research foundation concerning student engagement (Coates, 2009; Kuh, 2004), provides a holistic view of an institutions level of student engagement.

While the NSSE focuses on institutional level engagement, the CLASSE focuses on classroom-level engagement. CLASSE is also not grade specific, whereas the NSSE is typically targeted to first-year and senior students (Ouimet, 2011). The engagement indicators remain constant within both the NSSE and CLASSE; the major alteration is the wording to be class specific versus institution-wide (Ouimet \& Smallwood, 2005). Both surveys included 41 items among five constructs, including: 1$)$ engagement activities $(n=19)$, 


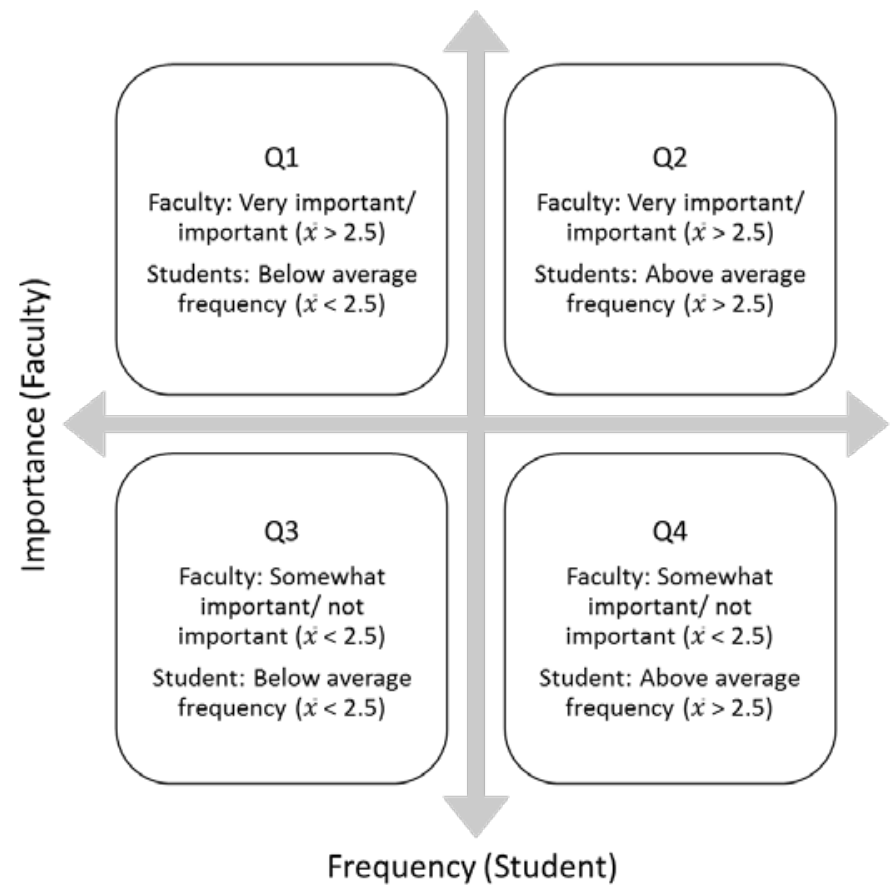

Figure 2. Diagram of the 2 x 2 quadrant analysis. Adapted from “Assessment Measures: CLASSE-The Class-Level Survey of Student Engagement,” by J. A. Ouimet and R. A. Smallwood, 2005, Assessment Update, 17, p. 15. Copyright 2005 by John Wiley \& Sons, Inc.

2) cognitive skills $(n=5)$, 3) other educational practices $(n=10)$, 4) class atmosphere $(n=4)$, and 5) demographics $(n=3)$. The student version of the instrument included an open-ended section which allowed students the opportunity to provide additional comments.

CLASSE is a localized engagement survey derived from NSSE and is governed by the NSSE as well as The Trustees of Indiana University. Therefore, the first step in utilizing the CLASSE required determining institutional eligibility. This was achieved by reviewing the most recent administration of the NSSE at ISU. To be eligible to utilize the CLASSE, an institution must have administered the NSSE within the last three years. At the time of examining eligibility, ISU was deemed eligible due to NSSE participation in 2011, 2013, and 2016 (National Survey of Student Engagement, 2016).

The CLASSE Student $_{\text {Survey was administered to all }}$ students enrolled in AGEDS 450 during the fall 2015 ( $n$ $=61)$ and spring $2016(n=60)$. The fall administration yielded an $88.5 \%(n=54)$ response rate and the spring iteration yielded an $86.6 \%(n=52)$ response rate. Accounting for both semesters of administration, the total response rate was $87.6 \%(n=106)$. No efforts beyond the initial administration were attempted based on a response rate greater than $85 \%$ (Lindner, Murphy, \& Briers, 2001). Additionally, because the applied purpose of the data was to inform practice within the given course, an $87.6 \%$ response rate was deemed acceptable by the researchers. The CLASSE Faculty instrument was administered to all individuals involved in planning, delivering, or approving curriculum (instructor, farm operator, and the professor-in-charge) within the course $(n=3)$ and yielded a $100 \%$ response rate prior to the start of the 16-week course. Measures of central tendency (i.e., means and standard deviations) for the CLASSE student and CLASSE Faculty $_{\text {responses were }}$ calculated with SPSS 19.0. The means for the CLASSE $_{\text {Student }}$ instrument were then compared to CLASSE $_{\text {Faculty }}$ instrument means in a 2x2 quadrant analysis (Ouimet, 2011; Smallwood, 2010). Figure 2 depicts the quadrant descriptions and their corresponding statistical thresholds.

Items in the top left quadrant (Q1) were rated very important or important by faculty but student responses indicated a below average frequency of participation in activities related to student engagement. Items in the top right quadrant (Q2) were rated as very important or important by faculty and reported by students as having above average participation in those engagement related activities. The lower left quadrant (Q3) contained items instructors rated as somewhat important or not important with students reporting below average participation in those activities. Quadrant four (Q4), the lower right quadrant, housed items rated somewhat important or not important by faculty and had above 
Journal of Research in Technical Careers

Table 1. Importance of Engagement Activities by Instructors in AGEDS 450 ( $\mathrm{n}=3$ )

\begin{tabular}{|c|c|c|c|c|}
\hline \multirow[b]{2}{*}{ Engagement Indicators } & \multirow[b]{2}{*}{$M$} & \multirow[b]{2}{*}{$S D$} & \multicolumn{2}{|c|}{ Range } \\
\hline & & & Min & Max \\
\hline $\begin{array}{l}\text { Work on a paper or a project in your AGEDS } 450 \text { class that requires integrating ideas or } \\
\text { information from various sources }\end{array}$ & 4.00 & 0.00 & 4.00 & 4.00 \\
\hline Come to your AGEDS 450 class having completed readings or assignments & 4.00 & 0.00 & 4.00 & 4.00 \\
\hline Work with other students on projects during your AGEDS 450 class & 4.00 & 0.00 & 4.00 & 4.00 \\
\hline $\begin{array}{l}\text { Put together ideas or concepts from different courses when completing assignments or } \\
\text { during class discussions in your AGEDS } 450 \text { class }\end{array}$ & 4.00 & 0.00 & 4.00 & 4.00 \\
\hline Make a class presentation in your AGEDS 450 class & 4.00 & 0.00 & 4.00 & 4.00 \\
\hline $\begin{array}{l}\text { Receive prompt written or oral feedback from you on their academic performance in } \\
\text { your AGEDS } 450 \text { class }\end{array}$ & 4.00 & 0.00 & 4.00 & 4.00 \\
\hline Ask questions during your AGEDS 450 class & 3.67 & 0.57 & 3.00 & 4.00 \\
\hline Contribute to class discussions that occur during your AGEDS 450 class & 3.67 & 0.57 & 3.00 & 4.00 \\
\hline Discuss grades or assignments with you as the instructor of your AGEDS 450 class & 3.67 & 0.57 & 3.00 & 3.00 \\
\hline $\begin{array}{l}\text { Prepare two or more drafts of a paper or assignment in your AGEDS } 450 \text { class before } \\
\text { turning it in }\end{array}$ & 3.33 & 0.57 & 3.00 & 4.00 \\
\hline Tutor or teach other students in your AGEDS 450 class & 3.33 & 0.57 & 3.00 & 4.00 \\
\hline Use email to communicate with you as the instructor of your AGEDS 450 class & 3.33 & 1.15 & 2.00 & 4.00 \\
\hline $\begin{array}{l}\text { Work harder than they think they can to meet your standards or expectations in your } \\
\text { AGEDS } 450 \text { class }\end{array}$ & 3.33 & 0.57 & 3.00 & 4.00 \\
\hline Work with classmates outside of your AGEDS 450 class to prepare class assignments & 3.00 & 1.00 & 2.00 & 4.00 \\
\hline $\begin{array}{l}\text { Use an electronic medium (list-serv, chat group, Internet, instant messaging, etc.) to } \\
\text { discuss or complete an assignment in your AGEDS } 450 \text { class }\end{array}$ & 3.00 & 1.00 & 2.00 & 4.00 \\
\hline $\begin{array}{l}\text { Discuss ideas from your AGEDS } 450 \text { class with others outside of class (students, family } \\
\text { members, coworkers, etc.) }\end{array}$ & 3.00 & 1.00 & 2.00 & 4.00 \\
\hline $\begin{array}{l}\text { Include diverse perspectives (different races, religions, genders, political beliefs, etc.) in } \\
\text { class discussions or writing assignments in your AGEDS } 450 \text { class }\end{array}$ & 2.67 & 0.57 & 2.00 & 3.00 \\
\hline $\begin{array}{l}\text { Participate in a community-based project (e.g., service learning) as part of your AGEDS } \\
450 \text { class }\end{array}$ & 2.67 & 1.15 & 2.00 & 4.00 \\
\hline Discuss ideas from your AGEDS 450 readings or classes with you outside of class & 2.00 & 1.00 & 1.00 & 4.00 \\
\hline
\end{tabular}

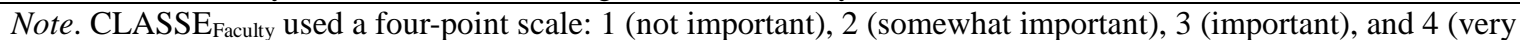
important)

average participation per student reports. Q1 and Q4 are known as misses, as they show discrepancies between faculty rated importance and student frequencies; while Q2 and Q3 are known as hits, which show congruency between what faculty reports compared to what students reported doing.

Bempechat and Shernoff (2012) noted the difficulty that arises in attempting to measure student engagement through observer ratings, as it is not always an observable characteristic. Thus, student self-reported data was utilized based on its practicality and its ability to measure non-observable indicators of engagement (Mandernach, 2015). Instructors of the course studied are the primary beneficiaries of the results; however, results from this study could also provide valuable insight to engagement levels in a flipped, TBLformatted course.

\section{Results}

The purpose of this study was to determine congruency between student participation in engagement-specific activities and instructors' perceived value of those same engagement practices within the capstone AGEDS 450. Most respondents were male (78.3\%) in their senior year (73.6\%). All the respondents were pursuing an agricultural studies degree (100\%), with six (5.7\%) and one $(0.9 \%)$ pursuing minors in agronomy and agricultural education, respectively.

Research objective one sought to describe the instructor-rated importance of specific activities linked with good practice (i.e., engagement indicators) in the AGEDS 450. Measures of central tendencies (means and standard deviations) are reported for each item by section to describe the importance placed on each activity by individuals with educative responsibilities within AGEDS 450. Relating to engagement activities, instructors unanimously rated the following six items as very important $(M=4.00, S D=0.00)$ for students to be successful in AGEDS 450; integrating information from various sources into projects or papers, completing assignments or readings before coming to class, working with other students during class, putting ideas from other courses together during class discussions, presenting to the class, and receiving prompt written/oral feedback on academic performance. The 
Table 2. Importance of Cognitive Skills by Instructors in AGEDS $450(\mathrm{n}=3)$

\begin{tabular}{|c|c|c|c|c|}
\hline \multirow[b]{2}{*}{ Engagement Indicators } & \multirow[b]{2}{*}{$M$} & \multirow[b]{2}{*}{$S D$} & \multicolumn{2}{|c|}{ Range } \\
\hline & & & Min & Max \\
\hline Applying theories or concepts to practical problems or in new situations & 4.00 & 0.00 & 4.00 & 4.00 \\
\hline $\begin{array}{l}\text { Analyzing the basic elements of an idea, experience, or theory, such as examining a } \\
\text { particular case or situation in depth and considering its components }\end{array}$ & 3.67 & 0.57 & 3.00 & 4.00 \\
\hline $\begin{array}{l}\text { Synthesizing and organizing ideas, information, or experiences into new, more complex } \\
\text { interpretations and relationships }\end{array}$ & 3.67 & 0.57 & 3.00 & 4.00 \\
\hline $\begin{array}{l}\text { Making judgments about the value of information, arguments, or methods, such as } \\
\text { examining how others gathered and interpreted data and assessing the soundness of } \\
\text { their conclusions }\end{array}$ & 3.67 & 0.57 & 3.00 & 4.00 \\
\hline $\begin{array}{l}\text { Memorizing facts, ideas, or methods from your courses and readings so you can repeat } \\
\text { them in pretty much the same form }\end{array}$ & 2.00 & 1.00 & 1.00 & 3.00 \\
\hline \multicolumn{5}{|c|}{$\begin{array}{l}\text { Note. CLASSE } \\
\text { impoculty used a four-point scale: } 1 \text { (not important), } 2 \text { (somewhat important), } 3 \text { (important), and } 4 \text { (very }\end{array}$} \\
\hline \multicolumn{5}{|l|}{ Table 3. Importance of Other Educational Practices by Instructors in AGEDS $450(n=3)$} \\
\hline Engagement Indicators & $M$ & $S D$ & Min & Max \\
\hline Attend AGEDS 450? & 4.00 & 0.00 & 4.00 & 4.00 \\
\hline Are interested in learning the AGEDS 450 course material? & 4.00 & 0.00 & 4.00 & 4.00 \\
\hline Are challenged to do their best work on the examinations they have in AGEDS 450 & 3.67 & 0.57 & 3.00 & 4.00 \\
\hline Prepare written papers or reports of more than 5 pages in length in AGEDS 450? & 3.33 & 0.57 & 3.00 & 4.00 \\
\hline $\begin{array}{l}\text { Participate in a study partnership with a classmate in your AGEDS } 450 \text { class to prepare } \\
\text { for a quiz or a test? }\end{array}$ & 3.33 & 1.15 & 2.00 & 4.00 \\
\hline Take notes in AGEDS 450? & 3.00 & 1.00 & 2.00 & 4.00 \\
\hline Review notes prior to the next scheduled meeting of your AGEDS 450 ? & 3.00 & 1.00 & 2.00 & 4.00 \\
\hline $\begin{array}{l}\text { Spend more than } 3 \text { hours during a typical week preparing for your AGEDS } 450 \\
\text { (studying, reading, doing homework or lab work, analyzing data, rehearsing, and other } \\
\text { academic matters)? }\end{array}$ & 2.67 & 0.57 & 2.00 & 3.00 \\
\hline $\begin{array}{l}\text { Have homework assignments during a typical week in your AGEDS } 450 \text { that take more } \\
\text { than one hour each to complete? }\end{array}$ & 2.00 & 1.73 & 1.00 & 4.00 \\
\hline $\begin{array}{l}\text { Attend a review session or help session to enhance their understanding of the content of } \\
\text { your AGEDS } 450 \text { ? }\end{array}$ & 1.67 & 0.57 & 1.00 & 2.00 \\
\hline
\end{tabular}

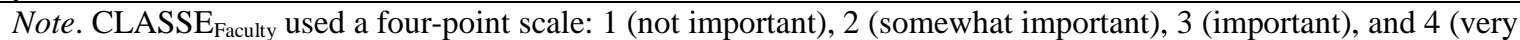
important)

lowest rated item, regarded as somewhat important ( $M=$ $2.00, S D=1.00$ ), was the need for students to discuss ideas from the class or related readings with instructors outside of class time. Table 1 displays all items within the engagement activities construct.

Instructors rated applying theories to practical problems $(M=4.00, S D=0.00)$ as the most important cognitive skill students should employ to be successful in AGEDS 450. Conversely, rote memorization was considered least important $(M=2.00, S D=1.00)$ for student success (Table 2).

Table 3 displays the importance instructors placed on engagement indicators within the other educational practices category. According to the instructors, homework that takes more than an hour to complete ( $M$ $=2.00, S D=1.73)$ and attending review sessions $(M=$ $1.67, S D=0.57$ ) are somewhat important or important, respectively, for students' success. Class attendance ( $M$ $=4.00, S D=0.00)$ and being interested in the course material $(M=4.00, S D=0.00)$ are very important for success in AGEDS 450.

All indicators within the classroom atmosphere category were rated as very important or important (see Table 4). Specifically, for students to be successful they should feel comfortable talking to the instructors $(M=$ $4.00, S D=0.00)$ and enjoy working with classmates $(M$ $=4.00, S D=0.00)$. 
Journal of Research in Technical Careers

Table 4. Importance of Classroom Atmosphere by Instructors in AGEDS $450(n=3)$

\begin{tabular}{|c|c|c|c|c|}
\hline \multirow[b]{2}{*}{ Engagement Indicators } & \multirow[b]{2}{*}{$M$} & \multirow[b]{2}{*}{$S D$} & \multicolumn{2}{|c|}{ Range } \\
\hline & & & Min & Max \\
\hline Being comfortable talking with you as the instructor of the AGEDS 450 & 4.00 & 0.00 & 4.00 & 4.00 \\
\hline Enjoying group work with their classmates in your AGEDS 450 class & 4.00 & 0.00 & 4.00 & 4.00 \\
\hline Finding the course material in your AGEDS 450 class to be difficult? & 3.33 & 0.57 & 3.00 & 4.00 \\
\hline Finding the lectures easy to follow in your AGEDS 450 class? & 3.00 & 1.00 & 2.00 & 4.00 \\
\hline
\end{tabular}

Table 5. Frequency of Student Participation in Engagement Activities $(\mathrm{n}=106)$

\begin{tabular}{|c|c|c|c|c|}
\hline \multirow[b]{2}{*}{ Engagement Indicators } & \multirow[b]{2}{*}{$M$} & \multirow[b]{2}{*}{$S D$} & \multicolumn{2}{|c|}{ Range } \\
\hline & & & Min & Max \\
\hline Worked with other students on projects during your AGEDS 450 class $^{\mathrm{a}}$ & 3.87 & 0.36 & 2.00 & 4.00 \\
\hline $\begin{array}{l}\text { Used an electronic medium (list-serv, chat group, Internet, instant messaging, etc.) to } \\
\text { discuss or complete an assignment in your AGEDS } 450 \text { class }^{a}\end{array}$ & 3.58 & 0.70 & 1.00 & 4.00 \\
\hline Asked questions during your AGEDS 450 class $^{\mathrm{a}}$ & 3.56 & 0.71 & 1.00 & 4.00 \\
\hline Made a class presentation in your AGEDS 450 class $^{\mathrm{b}}$ & 3.50 & 0.70 & 1.00 & 4.00 \\
\hline $\begin{array}{l}\text { Received prompt written or oral feedback on your academic performance from your } \\
\text { AGEDS } 450 \text { instructor }{ }^{c}\end{array}$ & 3.41 & 0.37 & 1.00 & 4.00 \\
\hline $\begin{array}{l}\text { Worked on a paper or a project in your AGEDS 450class that required integrating } \\
\text { ideas or information from various sources }{ }^{\mathrm{a}}\end{array}$ & 3.39 & 0.68 & 2.00 & 4.00 \\
\hline $\begin{array}{l}\text { Put together ideas or concepts from different courses when completing assignments } \\
\text { or during class discussions in your AGEDS } 450 \text { class }^{\text {a }}\end{array}$ & 3.32 & 0.79 & 1.00 & 4.00 \\
\hline Contributed to a class discussion that occurred during AGEDS 450 class $^{\mathrm{a}}$ & 3.29 & 0.80 & 1.00 & 4.00 \\
\hline $\begin{array}{l}\text { Worked harder than you thought you could to meet your AGEDS } 450 \text { instructor's } \\
\text { standards or expectations }{ }^{c}\end{array}$ & 3.13 & 0.84 & 1.00 & 4.00 \\
\hline $\begin{array}{l}\text { Discussed ideas from your AGEDS 450with others outside of class (students, family } \\
\text { members, coworkers, etc.) }\end{array}$ & 3.00 & 0.89 & 1.00 & 4.00 \\
\hline Used email to communicate with the instructor of your AGEDS 450 class $^{\mathrm{a}}$ & 2.83 & 0.87 & 1.00 & 4.00 \\
\hline $\begin{array}{l}\text { Worked with classmates outside of your AGEDS 450class to prepare class } \\
\text { assignments }^{\mathrm{a}}\end{array}$ & 2.76 & 0.94 & 1.00 & 4.00 \\
\hline $\begin{array}{l}\text { Participated in a community-based project (e.g., service learning) as part of your } \\
\text { AGEDS } 450 \text { class }^{\mathrm{b}}\end{array}$ & 2.49 & 1.10 & 1.00 & 4.00 \\
\hline $\begin{array}{l}\text { Prepared two or more drafts of a paper or assignment in your AGEDS 450class } \\
\text { before turning it in }{ }^{\mathrm{a}}\end{array}$ & 2.47 & 0.73 & 1.00 & 4.00 \\
\hline Discussed grades or assignments with the instructor of your AGEDS 450 class $^{\mathrm{a}}$ & 2.46 & 0.85 & 1.00 & 4.00 \\
\hline Tutored or taught other students in your AGEDS 450 class $^{\mathrm{a}}$ & 2.32 & 0.91 & 1.00 & 4.00 \\
\hline $\begin{array}{l}\text { Included diverse perspectives (different races, religions, genders, political beliefs, } \\
\text { etc.) in class discussions or writing assignments in your AGEDS } 450 \text { class }^{\text {a }}\end{array}$ & 2.31 & 0.84 & 1.00 & 4.00 \\
\hline $\begin{array}{l}\text { Discussed ideas from your readings or classes with your AGEDS 450instructor } \\
\text { outside of class }^{\mathrm{b}}\end{array}$ & 2.25 & 1.05 & 1.00 & 4.00 \\
\hline Came to your AGEDS 450class without having completed readings or assignments ${ }^{\mathrm{a}}$ & 2.10 & 0.79 & 1.00 & 4.00 \\
\hline
\end{tabular}

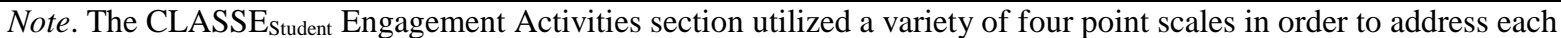
item. ${ }^{\mathrm{a}} 1$ (never), 2 (one or two times), 3 (three to five times), and 4 (more than five times). ${ }^{\mathrm{b}} 1$ (never), 2 (once), 3 (two times), and 4 (more than two times).

Research objective two sought to determine the frequency in which students participated in empirically supported, effective educational activities within AGEDS 450. Table 5 displays descriptive statistics for the frequency in which students participated in specific activities classified as engagement process indicators. On average, students reported working with classmates for projects during class $(M=3.87, S D=0.36)$ and utilizing an electronic medium to discuss or complete AGEDS 450 related assignments $(M=3.58, S D=0.70)$ most frequently. Conversely, students rarely (i.e., never/one or two times) came to class without completing readings or assignments $(M=2.10, S D=$ 0.79). Students also reported including diverse perspectives in class discussions or writing assignments $(M=2.31, S D=0.84)$ and discussing ideas from the 


\begin{tabular}{|c|c|c|c|c|}
\hline \multirow[b]{2}{*}{ Engagement Indicators } & \multirow[b]{2}{*}{$M$} & \multirow[b]{2}{*}{$S D$} & \multicolumn{2}{|c|}{ Range } \\
\hline & & & Min & Max \\
\hline Applying theories or concepts to practical problems or in new situations & 3.37 & 0.84 & 1.00 & 1.00 \\
\hline $\begin{array}{l}\text { Making judgments about the value of information, arguments, or methods, such as } \\
\text { examining how others gathered and interpreted data and assessing the soundness } \\
\text { of their conclusions }\end{array}$ & 3.35 & 0.82 & 1.00 & 1.00 \\
\hline $\begin{array}{l}\text { Analyzing the basic elements of an idea, experience, or theory, such as examining } \\
\text { a particular case or situation in depth and considering its components }\end{array}$ & 3.03 & 0.66 & 1.00 & 1.00 \\
\hline $\begin{array}{l}\text { Synthesizing and organizing ideas, information, or experiences into new, more } \\
\text { complex interpretations and relationships }\end{array}$ & 3.02 & 0.76 & 1.00 & 1.00 \\
\hline $\begin{array}{l}\text { Memorizing facts, ideas, or methods from your courses and readings so you can } \\
\text { repeat them in pretty much the same form }\end{array}$ & 2.29 & 0.88 & 1.00 & 4.00 \\
\hline
\end{tabular}

Table 7. Frequency of Student Participation in Other Educational Practices $(n=106)$

\begin{tabular}{|c|c|c|c|c|}
\hline \multirow[b]{2}{*}{ Engagement Indicators } & \multirow[b]{2}{*}{$M$} & \multirow[b]{2}{*}{$S D$} & \multicolumn{2}{|c|}{ Range } \\
\hline & & & Min & Max \\
\hline $\begin{array}{l}\text { How often in your AGEDS 450class have you been required to prepare written } \\
\text { papers or reports of more than } 5 \text { pages in length? }\end{array}$ & 3.58 & 0.63 & 2.00 & 4.00 \\
\hline How interested are you in learning the AGEDS 450course material? ${ }^{\mathrm{f}}$ & 3.39 & 0.59 & 1.00 & 4.00 \\
\hline $\begin{array}{l}\text { To what extent do the examinations in your AGEDS 450class challenge you to do } \\
\text { your best work? }\end{array}$ & 2.69 & 0.73 & 1.00 & 4.00 \\
\hline $\begin{array}{l}\text { How often have you participated in a study partnership with a classmate in your } \\
\text { AGEDS } 450 \text { class to prepare for a quiz or a test? }\end{array}$ & 1.94 & 0.97 & 1.00 & 4.00 \\
\hline $\begin{array}{l}\text { In a typical week in your AGEDS 450class, how many homework assignments } \\
\text { take you more than one hour each to complete? }\end{array}$ & 1.92 & 0.51 & 1.00 & 4.00 \\
\hline $\begin{array}{l}\text { In a typical week, how often do you spend more than } 3 \text { hours preparing for your } \\
\text { AGEDS } 450 \text { class (studying, reading, doing homework or lab work, analyzing data, } \\
\text { rehearsing, and other academic matters) }{ }^{d}\end{array}$ & 1.63 & 0.77 & 1.00 & 4.00 \\
\hline How frequently do you take notes in your AGEDS 450 class? ${ }^{\mathrm{d}}$ & 1.59 & 0.80 & 1.00 & 3.00 \\
\hline $\begin{array}{l}\text { How often do you review your notes prior to the next scheduled meeting in your } \\
\text { AGEDS } 450 \text { class? }\end{array}$ & 1.53 & 0.60 & 1.00 & 3.00 \\
\hline $\begin{array}{l}\text { How many times have you been absent so far this semester in your AGEDS } 450 \\
\text { class? }\end{array}$ & 1.38 & 0.52 & 1.00 & 3.00 \\
\hline $\begin{array}{l}\text { How often have you attended a review session or help session to enhance your } \\
\text { understanding of the content of your AGEDS } 450 \text { class? }\end{array}$ & 1.16 & 0.43 & 1.00 & 3.00 \\
\hline \multicolumn{5}{|c|}{ 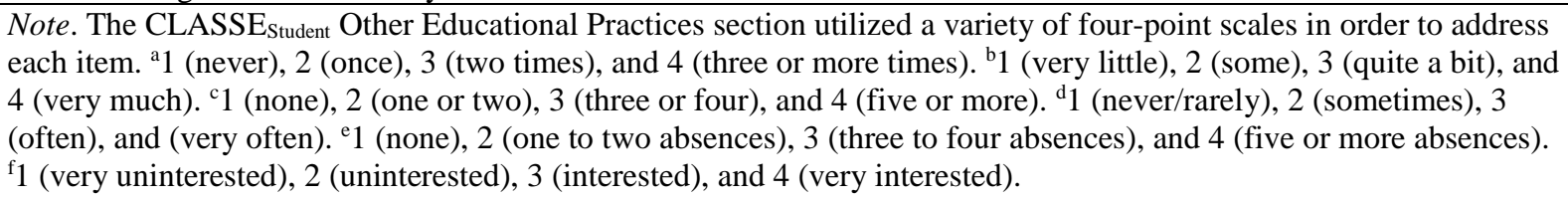 } \\
\hline
\end{tabular}

reading material utilized with the instructor outside of class time $(M=2.25, S D=1.05)$ less frequently as well.

Table 6 presents the cognitive skills employed by students during the AGEDS 450 course. Students reported utilizing rote memorization $(M=2.29, S D=$ 0.88 ) less frequently than the application of theories or concepts to practical problems in new situations $(M=$ $3.37, S D=0.84$ ).

The frequency of participation in activities in the other educational activities category are displayed in Table 7. Students reported being interested in learning the AGEDS 450 course material $(M=3.39, S D=0.59)$ and writing papers/reports of more than five pages in length $(M=3.58, S D=0.63)$. Students also reported rarely being absent from class $(M=1.38, S D=0.52)$, reviewing notes prior to class $(M=1.53, S D=0.60)$, and attending review sessions to enhance understanding of course material $(M=1.16, S D=0.43)$ were participated in less frequently by students.

Within the classroom atmosphere category, students indicated the lectures in the course to be somewhat easy $(M=2.32, S D=0.62)$ and that they were comfortable talking with the instructors of AGEDS $450(M=3.59, S D=0.61)$. Table 8 displays each engagement indicator within the classroom atmosphere category. 
Journal of Research in Technical Careers

Table 8. Frequency of Student Participation in Activities Contributing to the Class $(\mathrm{n}=106)$

\begin{tabular}{|c|c|c|c|c|}
\hline \multirow[b]{2}{*}{ Engagement Indicators } & \multirow[b]{2}{*}{$M$} & \multirow[b]{2}{*}{$S D$} & \multicolumn{2}{|c|}{ Range } \\
\hline & & & Min & $\operatorname{Max}$ \\
\hline How comfortable are you talking with the instructor of your AGEDS 450 class? & 3.59 & 0.61 & 2.00 & 4.00 \\
\hline $\begin{array}{l}\text { How much do you enjoy group work with your classmates in your AGEDS } 450 \\
\text { class? }^{\text {b }}\end{array}$ & 3.35 & 0.73 & 1.00 & 4.00 \\
\hline How easy is it to follow the lectures in your AGEDS 450 class? $^{\mathrm{d}}$ & 2.70 & 0.83 & 1.00 & 4.00 \\
\hline How difficult is the course material in your AGEDS 450 class? $^{c}$ & 2.32 & 0.62 & 1.00 & 3.00 \\
\hline
\end{tabular}

Note. The CLASSEStudent Other Educational Practices section utilized a variety of four point scales in order to address each item. ${ }^{\mathrm{a}} 1$ (uncomfortable), 2 (somewhat uncomfortable), 3 (comfortable), and 4 (very comfortable). ${ }^{\mathrm{b}} 1$ (very little), 2 (some), 3 (quite a bit), and 4 (very much). ${ }^{\mathrm{c}} 1$ (easy), 2 (somewhat difficult), 3 (difficult), and 4 (very difficult). ${ }^{\mathrm{d}} 1$ (difficult), 2 (somewhat easy), 3 (easy), and 4 (very easy).

Determining congruencies and discrepancies between the rates in which students participated in specific activities and the value instructors placed on those activities was the intent of research objective three. For misses (discrepancies), Q1 enveloped 10 (26.3\%) of the 38 engagement indicators while Q4 contained zero. For hits (congruencies), Q2 contained $24(63.2 \%)$ of the 38 indicators while Q3 was comprised of four $(10.5 \%)$ of the engagement indicators. Q2, the highest level of congruency, indicated that students reported participating in those activities at above average frequencies, and faculty rated those activities as very important or important. Items within Q2 included asking questions during class, contributing to class discussions, including diverse perspectives on writing assignments, integrating ideas or concepts from other classes for assignments, making judgments about the value of information and validity of sources, synthesizing and organizing ideas into more complex relationships, being comfortable talking with the instructors, and applying theories or concepts to practical problems. Q3 indicated the frequency in which students memorize facts in order to repeat them in the same manner, attend review sessions, or spend more than one hour per week on homework assignments was low while concurrently being regarded as only somewhat important/not important by the instructors. Q1 reported items rated as very important/important by the instructors but had below average student participation. Items within this quadrant included preparing two or more drafts of a paper or assignment before turning it in, including diverse perspectives (e.g., different races, religions, genders, etc.), tutoring other students, taking notes, reviewing notes, and finding the course material difficult.

\section{Conclusions and Discussion}

It should be noted that the data presented here is representative of a homogenous population regarding educational degree pursuit. Additionally, no specific data is available regarding the psychometric properties of CLASSE. However, according to Carle, Jaffee, and Miller (2009), the limited between-survey differences
(NSSE and CLASSE) should result in acceptable reliability coefficients ( $\alpha=0.85$ to 0.90$)$ (Kuh, 2001). NSSE and CLASSE have both been recognized as nationally-normed and standardized instruments whose response process, content, conceptual, concurrent, predictive, known groups, and consequential validity has been extensively tested.

This study displayed a useful heuristic process for instructors to position student engagement information at the classroom level. To rise to the call in developing engaging learning environments (Roberts et al., 2016), faculty members should consider utilizing the CLASSE instrument, or similar instruments, to determine discrepancies between student-reported and instructorvalued engagement activities. The localization of engagement data can serve as a useful supplement to other course evaluations (Laird, Smallwood, NiskodéDossett, \& Garver, 2009). In objective one, instructors with educative responsibilities for the AGEDS 450 provided the value (importance) placed on specific engagement activities. Aligning with the definition of a capstone course and the required learning activities in Crunkilton et al.'s (1997) framework, instructors rated integrating ideas and information from previous courses to in-class discussions and in completing assignments, projects, or papers as very important. Instructors also felt it was important for students to complete written reports, work with their peers, and communicate with the instructors. The utilization of higher order thinking skills was regarded as important for students to be successful.

For objective two, students reported their frequency of participation in specific engagement activities within the AGEDS 450. Students worked collaboratively to apply theories or concepts to practical problems, utilized technology to complete coursework, asked questions during class, and were interested in learning the course content. These items aligned with the outcomes and required learning activities recommended for inclusion in capstone courses according to Crunkilton et al. (1997). Student responses indicated an emphasis on the utilization of higher order cognitive skills as well as the perception of a safe classroom atmosphere.

Engagement is of paramount importance at all levels of education (Kuh, 2003). Therefore, activities 
empirically linked to student engagement (process indicators) (Chickering \& Gamson, 1987; Kuh et al., 2007) are deserving of considerable attention in curriculum design. This study supported previous literature, which found high levels of student engagement in active, TBL formatted courses (Lightner et al., 2007; Tucker, 2012). Our overall conclusion is that within a TBL-formatted capstone course, students were actively engaged in the learning process, both physically and psychologically, which leads to student development in several areas (Astin, 1999). Astin (1999) posited that all institutional practices are able to be evaluated based on the degree in which they increase or reduce student involvement. With respect to that statement, the TBL-formatted AGEDS 450 was successful in fostering student involvement.

\section{Recommendations and Implications}

Information gleaned from instruments such as CLASSE has implications for instructors in higher education and can be useful in determining the benefits of new pedagogies highlighting various instructional innovations employed by instructors within colleges of agriculture (Maxwell, et al., 2011). Additionally, this preliminary investigation offers insight on engagement promoted with a student-centered teaching approach; those needing validation as potential “...present day best practices and research-based pedagogies...” (Edgar et al., 2016, p. 39). As such, this study led to several recommendations for future inquiry.

The first recommendation stems from the importance of student engagement for long-term outcomes. We suggest that a series of longitudinal studies be conducted to examine long-term outcomes as they relate to student involvement and engagement. These data could be useful in validating Kuh et al.'s (2007) assertion that student engagement is linked to student satisfaction, employment, and lifelong learning skills. Furthermore, resulting data would be beneficial for colleges of agriculture in the promotion of and recruiting for various degree programs. The data could be further utilized to inform potential students and various stakeholders about the level of engagement in courses, departments, or entire degree programs.

We also recommended that a unified effort within agricultural education be implemented to develop a valid instrument for measuring student engagement at the local (classroom) level. As noted by Marx et al. (2016), much of the student engagement research is conducted at the institutional level. Research conducted at the institutional level provides many options in creating an empirically grounded instrument that can be psychometrically validated. The CLASSE instrument may potentially provide a starting point. The effort should involve experts from across the discipline of agricultural education in an effort to address the multidimensionality of student engagement.
Finally, we suggest faculty members within agricultural education work to ensure students are actively involved in the learning process. This could be conceptualized through strategic course revisions or targeted professional development programs for faculty members (Balschweid et al., 2014; Blickenstaff et al., 2015). Astin (1999) noted that involvement theory emphasizes students actively participating in the learning process. Idealistically, these course revisions or professional development programs would contribute to a decrease in faculty reporting lecturing as the teaching modality in which they feel most efficacious (Wardlow \& Johnson, 1999). Course activities planned with active learning strategies should promote student engagement (Estepp \& Roberts, 2013), a known indicator of longterm outcomes (Kuh et al. 2007). Perhaps meaningful, engaged, learning in all environments can become a reality across the discipline with the adoption of studentcentered teaching methods that emphasize the active application of content through structured problem solving and decision-making activities.

\section{References}

Appleton, J. J., Christenson, S. L., \& Furlong, M. J. (2008). Student engagement with school: Critical conceptual and methodological issues of the construct. Psychology in the Schools, 45(5), 369386. https://doi.org/10.1002/pits.20303

Appleton, J. J., Christenson, S. L., Kim, D., \& Reschly, A. L. (2006). Measuring cognitive and psychological engagement: Validation of the student engagement instrument. Journal of School Psychology, 44(2006), 427-445. https://doi.org/10.1016/j.jsp.2006.04.002

Astin, A. W. (1975). Preventing Students from Dropping Out. San Francisco, CA: Jossey-Bass Inc.

Astin, A. W. (1999). Student involvement: A developmental theory for higher education. Journal of College Student Development, 40(5), 518-529. https://doi.org/http://psycnet.apa.org/psycinfo/1999 -01418-006

Axelson, R. D., \& Flick, A. (2011). Defining student engagement. Change: The Magazine of Higher Learning, 43(1), 38-43. https://doi.org/10.1080/00091383.2011.533096

Balschweid, M., Knobloch, N. A., \& Hains, B. J. (2014). Teaching introductory life science courses in colleges of agriculture: Faculty experiences. Journal of Agricultural Education, 55(4), 162-175. https://doi.org/10.5032/jae.2014.04162

Bangert, A. W. (2004). The Seven principles of good practice: A framework for evaluating on-line teaching. The Internet and Higher Education, 7(3), 217-232. https://doi.org/10.1016/j.iheduc.2004.06.003

Banta, T. W., Pike, G. R., \& Hansen, M. J. (2009). The use of engagement data in accreditation, planning, 
and assessment. New Directions for Institutional

Research, 2009(141), 21-34.

https://doi.org/10.1002/ir.284

Bempechat, J., \& Shernoff, D. J. (2012). Parental influences on achievement motivation and student engagement. In S. L. Christenson, A. L. Reschly, \& C. Wylie (Eds.), Handbook of Research on Student Engagement (pp. 315-342). https://doi.org/10.1007/978-1-4614-2018-7_15

Blickenstaff, S. M., Wolf, K. J., Falk, J. M., \& Foltz, J. C. (2015). College of agriculture faculty perceptions of student skills, faculty competence in teaching areas and barriers to improving teaching. NACTA Journal, 59(3), 219-226.

Bowen, S. (2005). Engaged learning: Are we all on the same page? Peer Review, 7(2), 4-7.

Carle, A. C., Jaffee, D., \& Miller, D. (2009). Engaging college science students and changing academic achievement with technology: A quasiexperimental preliminary investigation. Computers \& Education, 52(2), 376-380. https://doi.org/10.1016/j.compedu.2008.09.005

Chalmers, D., \& Fuller, R. (1996). Teaching for learning at university: Theory and practice. United Kingdom: Routledge Falmer.

Chickering, A. W., \& Gamson, Z. F. (1987). Seven principles for good practice in undergraduate education. AAHE Bulletin, 39, 3-7.

Chickering, A. W., \& Gamson, Z. F. (1999). Development and adaptations of the Seven principles for good practice in undergraduate education. New Directions for Teaching and Learning, 1999(80), 75-81. https://doi.org/10.1002/tl.8006

Coates, H. (2009). Development of the Australasian survey of student engagement (AUSSE). Higher Education, 60(1), 1-17. https://doi.org/10.1007/s10734-009-9281-2

Cooper, J. L., \& Robinson, P. (2000). The argument for making large classes seem small. In J. MacGregor, J. L. Cooper, K. A. Smith, \& P. Robinsons (Eds.), New Directions for Teaching and Learning (pp. 516). https://doi.org/10.1002/tl.8101

Cruce, T. M., Wolniak, G. C., Seifert, T. A., \& Pascarella, E. T. (2006). Impacts of good practices on cognitive development, learning orientations, and graduate degree plans during the first year of college. Journal of College Student Development, 47(4), 365-383. https://doi.org/10.1353/csd.2006.0042

Crunkilton, J. R., Cepica, M. J., \& Fluker, P. L. (1997). Handbook on Implementing Capstone Courses in Colleges of Agriculture. (USDA award \# 94-38411-016). Washington, DC: United States Department of Agriculture.

Edgar, D. W., \& Retallick, M. S. (2016). Research priority 4: Meaningful, engaged learning in all environments. In T. G. Roberts, A. Harder, \& M. T. Brashears (Eds.), American Association for
Agricultural Education national research agenda: 2016-2020 (pp. 37-40). Gainesville, FL:

Department of Agricultural Education and Communication.

Estepp, C. M., \& Roberts, T. G. (2013). Teacher behaviors contributing to student content engagement: A socially constructed consensus of undergraduate students in a college of agriculture. Journal of Agricultural Education, 54(1), 97-110. https://doi.org/10.5032/jae.2013.01097

Ewell, P. T. (1996). The current pattern of state-level assessment: Results of a national inventory. Assessment Update, 8(3), 1-15. https://doi.org/10.1002/au.3650080302

Ewell, P. T., \& Jones, D. P. (1996). Indicators of “Good Practice” In Undergraduate Education: A Handbook for Development and Implementation. Retrieved from http://files.eric.ed.gov/fulltext/ED403828.pdf

Ewing, J. C., \& Whittington, M. S. (2009). Describing the cognitive level of professor discourse and student Cognition in college of agriculture class sessions. Journal of Agricultural Education, 50(4), 36-49. https://doi.org/10.5032/jae.2009.04036

Finn, J. D., \& Zimmer, K. S. (2012). Student engagement: What is it? Why does it matter? In S. L. Christenson, A. L. Reschly, \& C. Wylie (Eds.), Handbook of Research on Student Engagement (pp. 97-132). https://doi.org/10.1007/978-1-4614-20187 -5

Hemsley-Brown, J., \& Sharp, C. (2003). The use of research to improve professional practice: A systematic review of the literature. Oxford Review of Education, 29(4), 449-470. https://doi.org/10.2307/3595456

Hu, S., \& Kuh, G. D. (2002). Being (dis) engaged in educationally purposeful activities: The influences of student and institutional characteristics. Research in Higher Education, 43(5), 555-575. https://doi.org/10.1023/a:1020114231387

Jimerson, S. R., Campos, E., \& Greif, J. L. (2003). Toward an understanding of definitions and measures of school engagement and related terms. The California School Psychologist, 8, 7-27.

Kuh, G. D. (2001). Assessing what really matters to student learning inside the national survey of student engagement. Change: The Magazine of Higher Learning, 33(3), 10-17. https://doi.org/10.1080/00091380109601795

Kuh, G. D. (2003). What we're learning about student engagement from NSSE: Benchmarks for effective educational practices. Change: The Magazine of Higher Learning, 35(2), 24-32. https://doi.org/10.1080/00091380309604090

Kuh, G. D. (2004). The National Survey of Student Engagement: Conceptual framework and overview of Psychometric properties. Retrieved from http://nsse.indiana.edu/2004_annual_report/pdf/200 4_conceptual_framework.pdf 
Kuh, G. D. (2009). The national survey of student engagement: Conceptual and empirical foundations. New Directions for Institutional Research, 2009(141), 5-20. https://doi.org/10.1002/ir.283

Kuh, G. D., Kinzie, J., Buckley, J. A., Bridges, B. K., \& Hayek, J. C. (2007). Piecing together the student success puzzle: Research, propositions, and recommendations. ASHE Higher Education Report, 32(5), 1-182. https://doi.org/10.1002/aehe.3205

Kuh, G. D., Pace, C. R., \& Vesper, N. (1997). The development of process indicators to estimate student gains associated with good practices in undergraduate education. Research in Higher Education, 38(4), 435-454. https://doi.org/10.1023/a:1024962526492

Laird, T. F. N., Smallwood, R., Niskodé-Dossett, A. S., \& Garver, A. K. (2009). Effectively involving faculty in the assessment of student engagement. New Directions for Institutional Research, 2009(141), 71-81. https://doi.org/10.1002/ir.287

Lam, S., Jimerson, S., Kikas, E., Cefai, C., Veiga, F. H., Nelson, B., ... Zollneritsch, J. (2012). Do girls and boys perceive themselves as equally engaged in school? The results of an international study from 12 countries. Journal of School Psychology, 50(1), 77-94. https://doi.org/10.1016/j.jsp.2011.07.004

Lightner, S., Bober, M. J., \& Willi, C. (2007). Teambased activities to promote engaged learning. College Teaching, 55(1), 5-18. https://doi.org/10.3200/ctch.55.1.5-18

Lindner, J. R., Murphy, T. H., \& Briers, G. E. (2001). The handling of non-response errors in social science survey research in agricultural and life sciences. Journal of Agricultural Education, 42(4), 43-53. https://doi.org/10.5032/jae.2001.04043

Mandernach, B. J. (2015). Assessment of student engagement in higher education: A synthesis of literature and assessment tools. International Journal of Learning, Teaching and Educational Research, 12(2), 1-14. Retrieved from http://ijlter.org/index.php/ijlter/article/view/367/pdf

Marx, A. A., Simonsen, J. C., \& Kitchel, T. (2016). Undergraduate student course engagement and the influence of student, Contextual, and teacher variables. Journal of Agricultural Education, 57(1), 212-228. https://doi.org/10.5032/jae.2016.01212

Maxwell, L. D., Vincent, S. K., \& Ball, A. L. (2011). Teaching effectively: Award winning faculty share their views. Journal of Agricultural Education, 52(4), 162-174. https://doi.org/10.5032/jae.2011.04162

McCarthy, J. P., \& Anderson, L. (2000). Active learning techniques versus traditional teaching styles: Two experiments from history and political science. Innovative Higher Education, 24(4), 279-294. https://doi.org/10.1023/b:ihie.0000047415.48495.0 5
McCormick, A. C., Kinzie, J., \& Gonyea, R. M. (2013). Student engagement: Bridging research and practice to improve the quality of undergraduate education. Higher Education: Handbook of Theory and Research, 28, 47-92. https://doi.org/10.1007/978-94-007-5836-0_2

McCubbins, O., Paulsen, T. H., \& Anderson, R. G. (2016). Student perceptions concerning their experience in a flipped undergraduate capstone course. Journal of Agricultural Education, 57(3), 70-86. https://doi.org/10.5032/jae.2016.03070

Mennenga, H. A. (2012). Development and psychometric testing of the team-based learning student assessment instrument. Nurse Educator, 37(4), 168-172. https://doi.org/10.1097/nne.0b013e31825a87cc

Michaelsen, L. K., Knight, A. B., \& Fink, D. L. (Eds.). (2004). Team-Based Learning: A Transformative Use of Small Groups in College Teaching. Sterling, VA: Stylus Publishing.

Michaelsen, L. K., Sweet, M., \& Parmalee, D. X. (2008). Team-based learning: Small group learning's next big step. New Directions for Teaching and Learning, 116, 7-27.

Ouimet, J. A. (2011). Enhancing student success through faculty development: The classroom survey of student engagement. Journal of Higher Education and Lifelong Learning, 18, 115-120. https://doi.org/10.14943/J.HighEdu.18.115

Ouimet, J. A., \& Smallwood, R. A. (2005). Assessment measures: CLASSE-The class-level survey of student engagement. Assessment Update, 17(6), 13-15.

Pace, R. C. (1984). Measuring the quality of college student experiences: An account of the development and use of the College Student Experience Questionnaire. Retrieved from http://files.eric.ed.gov/fulltext/ED255099.pdf

National Survey of Student Engagement. (2014). Participating Institutions. Retrieved May 29, 2014, http://nsse.indiana.edu/

Paulsen, T. H. (2010). Collaborative decision making: A capstone agricultural business management course goal. NACTA Journal, 54(2), 2.

Reschly, A. L., \& Christenson, S. L. (2012). Jingle, jangle, and conceptual haziness: Evolution and future directions of the engagement construct. In S. L. Christenson, A. L. Reschly, \& C. Wylie (Eds.), Handbook of Research on Student Engagement (pp. 3-19). https://doi.org/10.1007/978-1-4614-20187_1

Roberts, T. G., Harder, A., \& Brashears, M. T. (2016). American Association for Agricultural Education national research agenda: 2016-2020. Retrieved from http://aaaeonline.org/resources/Documents/AAAE_ National_Research_Agenda_2016-2020.pdf

Shulman, L. S. (2002). Making differences: A table of learning. Change: The Magazine of Higher 
Learning, 34(6), 36-44. https://doi.org/10.1080/00091380209605567

Sinclair, M. F., Christenson, S. L., Lehr, C. A., \& Anderson, A. R. (2003). Facilitating student engagement: Lessons learned from check and connect longitudinal studies. The California School Psychologist, 8, 29-41. Retrieved from http://edpsych.utah.edu/school-

psych/_documents/grants/autism-traininggrant/CSP2003.pdf\#page $=9$

Smallwood, R. A. (2008). CLASSE: Overview. Retrieved April 15, 2016, from The University of Alabama Academic Affairs, http://www.assessment.ua.edu/CLASSE/Overview. htm

Smallwood, R. A. (2010). CLASSE: Results. Retrieved April 15, 2016, from The University of Alabama Academic Affairs, http://www.assessment.ua.edu/CLASSE/Results.ht $\mathrm{m}$
Smallwood, R. A., \& Ouimet, J. (2009). CLASSE: Measuring student engagement at the classroom level. In T. W. Banta, E. A. Jones, \& K. Black E, (Eds.), Designing effective assessment: Principles and profiles of good practice (pp. 193-197). San Francisco, CA: Jossey-Bass.

Smith, K. A., Sheppard, S. D., Johnson, D. W., \& Johnson, R. T. (2005). Pedagogies of engagement: Classroom-based practices. Journal of Engineering Education, 94(1), 87-101. https://doi.org/10.1002/j.2168-9830.2005.tb00831.x

Tucker, B. (2012). The flipped classroom: Online instruction at home frees class time for learning. Education Next, 12(1), 2-10.

Wardlow, G. W., \& Johnson, D. M. (1999). Level of teaching skills and interest in teaching improvement as perceived by faculty in a landgrant college of agriculture. Journal of Agricultural Education, 40(4), 47-56. https://doi.org/10.5032/jae.1999.04047 